\title{
The effect of Narrative group Therapy on the Rate of Life Satisfaction among Aged Men living in the nursing home
}

\author{
Qaderi Bagajan $\mathrm{K}^{* 1}$, Nickbakht $\mathrm{I}^{2}$, Valad Baigi $\mathrm{E}^{3}$
}

\begin{abstract}
Intruduction and purpose: Elderly Population in the world and Iran rapidly grow, many of whom cannot care of themselves. Moreover, life satisfaction level decreases with increasing age, yet the elderlies who reside in nursing homes have lower rate in life satisfaction than who live in home. Whereas higher rate of life satisfaction results increased longevity and more wellness in elderlies, this study aimed to evaluate the effectiveness of narrative therapy in conjunction with life satisfaction in older men who live in the elderly center.
\end{abstract}

Materials and procedures: This study have semi-experimental design with implementation of the pretest and post-test on two groups (control and test). The study population consisted of all elderly men who live in nursing homes of Sanandaj city. For gather the data "life satisfaction questionnaire" was used. 30 elderly people were randomly selected and randomly assigned to two experimental and control groups. After implementing pre-test for both, the test and the control groups, intervention Group Counseling "Narrative Therapy" was administered to the experimental group. Finally, life satisfaction scale were measured for both groups and subsequently, after a month follow-up test was done.

Findings:Based on covariance analysis, there is a significant difference between control and experimental groups in post test $(\mathrm{p}<0.05)$, so, Group Counseling "Narrative Therapy" intervention had increased life satisfaction level among experimental group whereas there were not such an increase on the control group.

Conclusion: Using covariance tests and T-test the data was analyzed. Research findings indicate that the narrative therapy intervention, results to increased life satisfaction in elderlies, so result of this treatment can be sought to improve life satisfaction in Seniors.

Key words: Elderly people, life satisfaction ,Narrative therapy, Group Therapy

Received: 2015/10/31 Accepted: 2016/05/31

Copyright () 2018 Quarterly Journal of Geriatric Nursing.This is an open-access article distributed under the terms of the Creative Commons Attribution international 4.0 International License(http://creativecommons.org/licenses/by /4.0/) which permits copy and redistribute the material, in any medium or format, provided the original work is properly cited.

1. M.Sc in clinical Psychology, Faculty of Psychology and educational Sciences, Allameh Tabataba'i University,

Tehran. Iran. (Corresponding Author):E-mail: kawe.ghaderi@gmail.com

2. Msc in Social Work, Department of Social Sciences, Allameh Tabataba'i University, Tehran. Iran

3. Msc in Social Work, Department of Social Sciences, Allameh Tabataba'i University, Tehran. Iran 


\section{بررسى تاثير روايت درمانى گَروهى برميزان رضايت از زندكى مردان سالمند مستقر در مركز سالمندان}

كاوه قادرى بَّه جان "' عيسى نيك بخت"، اقبال ولدبيكىى

تاريخ دريافت مقاله: N/9 / /

تاريخ קذيرش مقاله: ||/س/هوس|

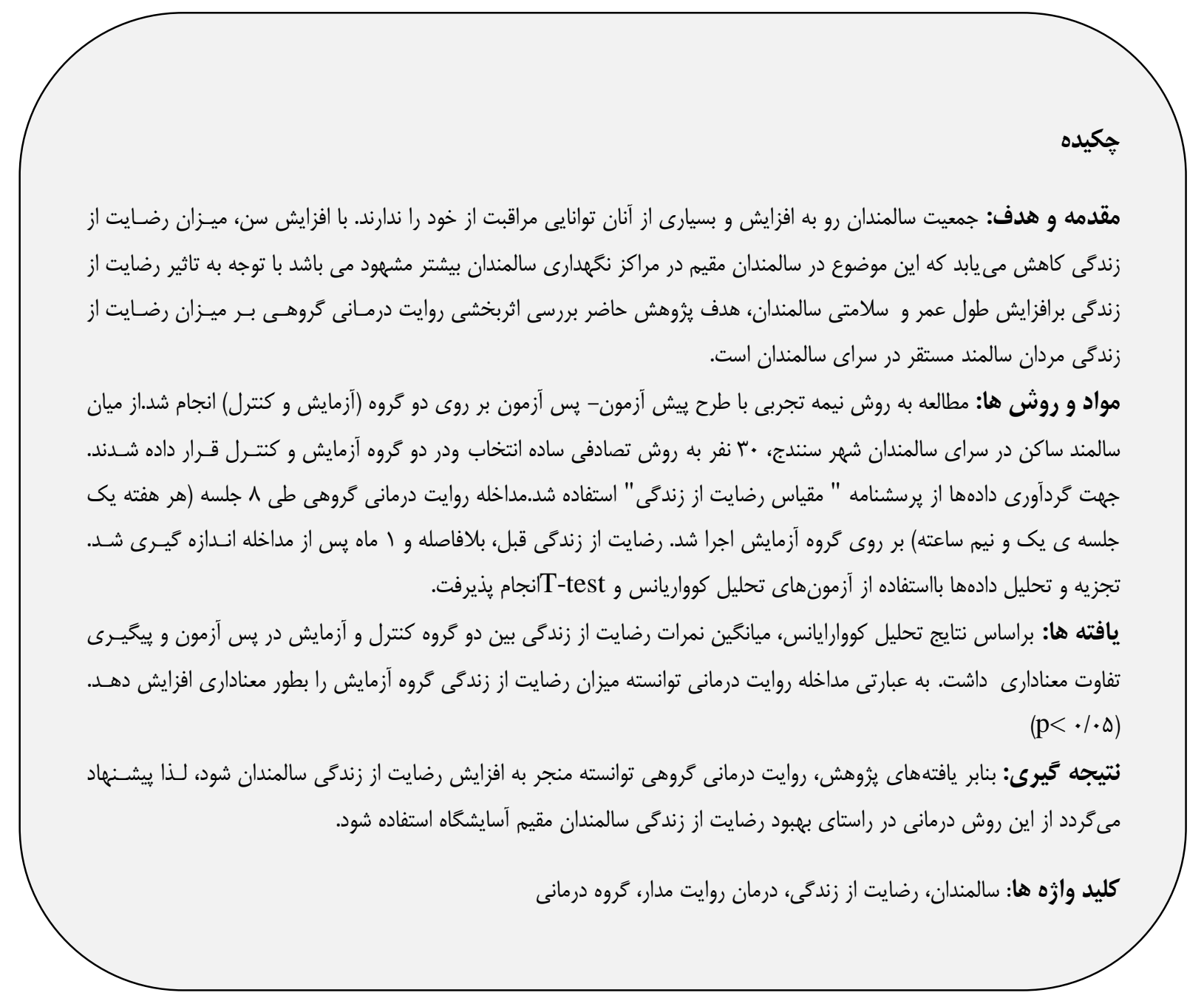

ا - دانشجوى كارشناسى ارشد روان شناسى بالينى، دانشكده روان شناسى و علوم تربيتى، دانشخاه علامه طباطبايى، تهران، ايران

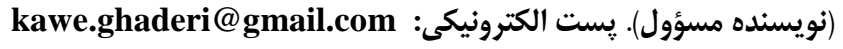

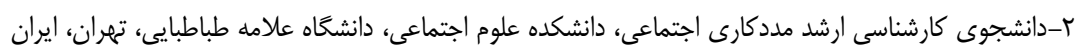

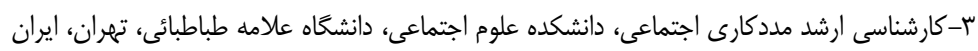


وخوشى ماوراى رويدادها و موقعيت هاى زندگى رادر يسى دارد[9].

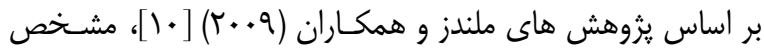
شده است كه با بالارفتن سن رضايت از زندگى كاهش مىيابدكـهـ. در سالمندان مقيم سراى سالمندان به خاطر محروميت ها عـاطفى ناشى از دورى از خانواده و فرزندان، طرد شـدكى از طـرف آنهـا و همجنين وابسـتَى بــه ديخــران در انجـام فعاليـت هـاى روزمـره احساس بى نقشى و مصرف كنتـدَى بييشـتر و نهايتـا رضـايت از زنــدى كمتـرى را بــه نسـبت سـالمندان مقـيم در خانـه تجربـهـ مى كنند[ [1].روشهاى درمانى بسيارى براى سالمندان مورد استفاده قرار ترفته است كه در اين ميان درمان هاى سـازه نحــر بـرخلاف تجربه نكَرها كه بر واقعيت عينى وتجربى وتوافقى تاكيد مى كنتـدو تمركز خود را روى ديدكاه منحصر به فرد ذهنى و قصه خود ساخته مراجعان قرار مى دهند، به طوريكه درمانجو و مراجعان را معطوف خود مى نمايند [III]. روايت درمانى به عنـوان يــ روش درمـانى

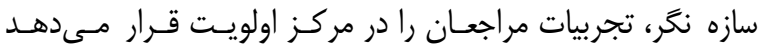

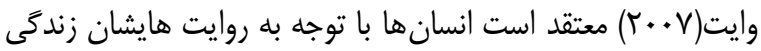
مى كنند و اين روايتها تعيين مى كنتـــ آنهـا جـهـ كسى هسـتند و

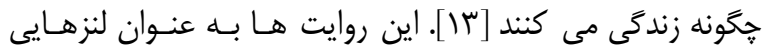
عمل مى كنند كه روايت هاى جديد و متفـاوت از روايـت مسـلط را فيلتر مى كنند و اجازه ورود به آنها را نمى دهند[أI]. نقش روايست هاى زندگى به حدى است كه تعيين مى كند مراجعـان جـهـ جِيـزى

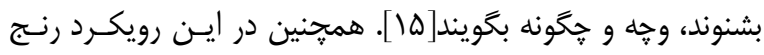
روانى به عنوان مسئله اى ديده مىشود كه از طريق ساختار بنـدى روايتى و هويتى فرد به وجود مىآيد[ع|].اين روش درمانى مبتنى
مطابق تعريف سازمان بهداشت جهانى سالمندى به محدوده سـنى

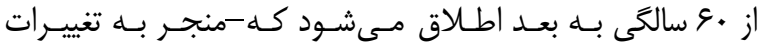
فيزيولوزيكى، روانى و اجتماعى درسالمندان مسىـود[ []، جمعيـت جهان بــه سـرعت رو بـهـ سـالمندى مسرود[ب]. درصـــ زيـادى از جمعيت سالمندى در كشورهاى در حال توسعه زندگى مى كنند كـهـ سهم كثور ايران از اين جمعيت قابل توجه است. بــهـ طـورى كـه، طبق داده هاى سازمان آمار ايران در سرشمارى سال هـاى هوبا،

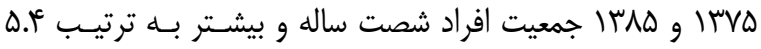

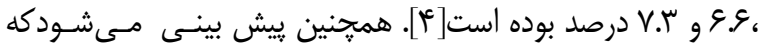
جمعيت سالمندان ايرانى در سال •ه+rبه بيش از צr ميليـون نفـر يعنى حدود V/ آ درصد از كل جمعيـت برســ [ه]. لازم بـه ذكـر است كه تعداد كثيرى از سالمندان براى مراقبت از خود نيازمند بــهـ. ديخران هستند ،بروز اختلال در انجام فعاليـت هـا، سـبب افـزايش وابستخى فرد شده و خطر بسترى شدن وى را در مراكز نخمهـدارى شبانه روزى افزايش مىدهند[؟]. رضـايت از زنــدَى يـك مفهـوم ذهنى و منحصر به فرد براى هر انسان است كه به ارزيابى شناختى يك شخص از زندگى اشـاره دارد[V]. رضـايت از زنـدكى قضـاوت كلى فرد از زندگى است كه ، بازتاب توازن ميان آرزوهاى شخص و وضعيت فعلى او است.[1] هر خه شكاف ميان سطح آرزوهاى فـرد و وضعيت عينى وى بيشتر شود، رضايت او كاهش مىيابد. رضايت از زندكَى شامل احساسات مثبت و خوشايند نسبت به زندگى اسـت كه رشد و يرورش خود ،افزايش انعطاف يذيرى براى به كـارگيرى مهارت ها در تعديل هيجانات، به دست آوردن قدرت حل مسـئله و توانايى براى تغيير ديدكاهها در جهت به دست آوردن احساس لذت 
معتقدند كه مددجويان كذشته خود را با داستان هايى كـه در زمـان حال نقل مى كنند مىسازند. پֶ. كذشـته را مسىتـوان بـا سـاختن روايتها يا داستان هاى جديد تغيير داد. روايت درمانكًان با افرادى

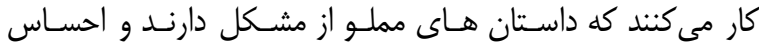
مى كنند كنترل خود را ازدست داده اندو توانايى تغيير آن را ندارنـــ

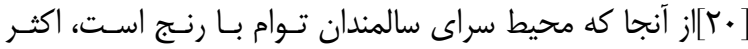
سالمندان احساس بدبينى و دلتنكى دارنـــ. بسـيارى از اينـان خـود

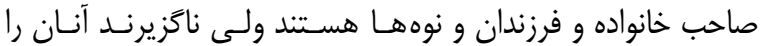
فراموش كنند و تا پايان عمر در آنجا زندگى كنــــ. برخى از آنـان دجار مشكلات روانى و برخى دهار درد و رنج غيــر قابـل تغييرنـد، نحترش بيشتر افراد نسبت به سالمندى منفى است[ آ] و زندگى در سراى سـالمندان بـا احسـاس طـرد شـــى كـهـ بــه همـراه خـود دارد،رضايت از زندگى را به ميزان بيشترى كاهش مى دهد .لـذا بـاــا در نظر داشتن اين تفاسير و به اين جهت كه ما در كشور خـود بـهـ طور فراگيرى با بديده سالمندى به ويـرَه سـالمندان مقيهم سـراى سالمندان روبه رو هستيم و از سـوى ديخـــر از آنجـا كـهـ براسـاس نظريه اريكسون فرد در سـنين سـالمندى بـه مـرور كذشــهـ خـود معيردازد، ما با يكى مـرور از كذشـته روبـهـ رو هسـتيم كـه نقـش روايتها را برجسته تر مى كند همֶٍنين از آنجا كه روايـت درمـانى

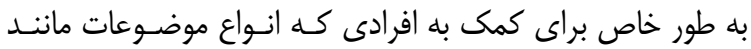
افسردگى، اضطراب و طرد شدگى را تجربه كرده اند توصـيه شـده است[بr]. ونهايتا به اين جهت كـه تـا كنـون يزوهشس بـه طـور مستقيم در اين رابطه انجام نشده لذا مطالعه حاضر به دنبال ياسخخ به اين سوال است كه آيا مداخله روايت درمانى گروهى مىتواند بر افزايش رضايت از زندگى سالمندان مقـيم آسايشــاه تـاثير داشـته
بر گزارش وقايع و روايت داستانى از زندگى فردى است،در واقع هر فردى تمايل دارد تا زندگى خود را مثل داستانى كه ابتدا و انتهـايى دارد روايت كند و براساس روايت و حكايتى كه از خود بيان مى كند نسبت به احساسات و كليت زندكى اش آكاه مسىشـود و تجربيـات جديدى كسب مى كند[IV]. مايكل وايت به عنوان بيشگام روايـت درمانى به بررسى نحوه اى كه افراد هويت خود را تشكيل مىدهند يرداخت و روايت درمانى را بر انسان شناسى فرهنگى، نظريه ادبى و فلسفه پِست مدرن استوار كرد. روايـت درمـانى بـهـ عنـوان يـــ رويكـرد مشـاركتى و غيـر تشخيصـى در روانشناسى ومـددكارى اجتماعى، مردم را در مركز و به عنوان متخصصين زندگى خودشان در نظر ميخيرد[11].هسته اصلى اين رويكرد عبارت است از فرآينـد كمك به افراد براى غلبه بـر مشكلاتشــان از راه دركيـر شـدن در

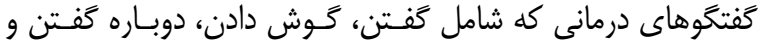
دوباره شنيدن داستانهاست به عبارتى روايت درمانى از روايت هاى كه افراد درباره خود مى گويند و باور دارند استفاده مى كند تا لنزهاى جديد و روايتها، تجربيات و آينــده جديـدى را بسـازد [19]. بريـان

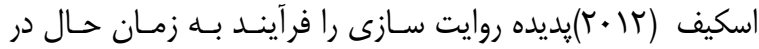
آوردن تجربيات مىداند كه مراجعان معنس هـاى زندگَيشـان را در يك زمان و مكان خاص با ديكران مىسازند. همجنين اين رويكرد مردم را متخصصان اصلى زندگيشان و مشكلات را به عنوان بخش هاى جداكانه از مردم مىيبندو براين اعتقاد است كـهـ مـردم داراى بسيارى از مهارت ها، باورها، ارزش ها و توانايى هايى هستند كه به آنها كمك مى كنــــــا اثـرات مشـكلات را در زندَّيشـان كـاهش دهند[با]. يكى از شَفتى هاى روايتها اين است كه باز، جارى و بى انتها هستند و وقتى داستان هايى كه ما درباره خود مسىسازيم تغيير كنند ما نيز تغيير مى كنـيم[|II]. بـر همــين مبنـا، درمـانكران 
شده ومورد استفاده قرار گرفته است، جوكار(عمسا) نيز در يزوهش خود آلفاى كرونباخ •^^\% را ززارش نمود[ب]]. به وسيله ى اين مقياس ييش آزمون بر روى دو حَروه آزمـايش و

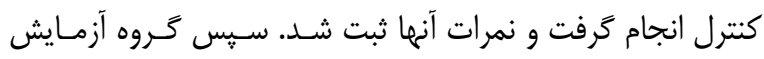
تحت درمان روايت درمانى گروهى طى هشت هفته هر هفته يـى جلسه ى يك ساعت و نيم قرار گَرفتند در اين مدت گَروه كنتـرل هيج مداخله اى دريافت نكرد. لازم به ذكر است كه طرح درمـانى همسو با برنامه هاى درمانى مايكل وايت و إِــتون [If] إجراشـــ.

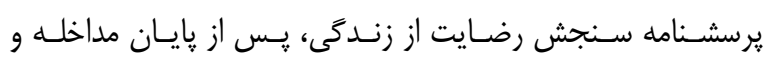
همجِنين يك ماه بعد توسط نمونه هاى يزوهش تكميل شد.

طرح درمان

براى استفاده از استراتزىها و تكنيكهــا طـرح درمـان مطـابق بــاـ روش وايت و إستون (•199)، ابتدا براى هر يـــ از افراد نمونـه، جلسه اى انفرادى جهت مصاحبه و مطـرح كـردن اهــاف درمـانى بركزار شد پِ از توافق جهت شركت در جلسـات رضـايت نامـهـ و

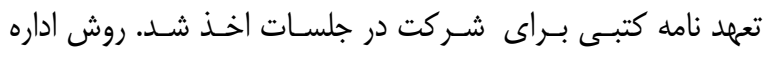
جلسات با استفاده از كَفت وگَوى مشاركتى و فعـال بـود. محتـواى جلسات به طور خلاصه شرح زير است:
اين مطالعه يك تحقيق نيمه تجربى است كـه در سـال سوسا در سراى سالمندان سنندج به صورت ييش آزمون-ِّ آزمون با گروه كنترل وآزمايش اجرا شـــ از روش نمونـــ كيــى قضـاوتى بـراى انتخاب شركت كنندكان مطالعه حاضر استفاده شد. بر همين اساس

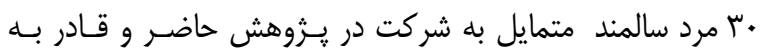
شركت درجلسات درمـانى را وواجـــ معيارهـاى ورود بــهـ يـروهش براى شركت در مطالعه حاضر انتخاب شدند. سِّ ايـن افـراد بـهـ صورت تصادفى در دو گروه آزمايش و كنترل قـرار داده شــند. در ايـن تحقيـق از يرسشــامه مقيـاس رضـايت از زنـدكى ( Life (Satisfaction Scales

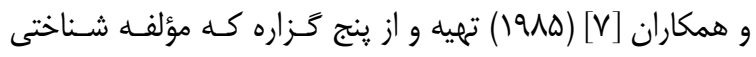
بهزيستى فاعلى را اندازه كيرى مى كند، تشكيل شده اسـت و بــراى

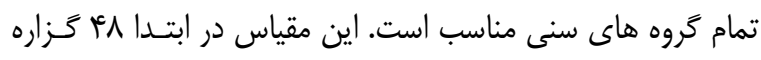
بود كه پِ از بررسى هاى متعدد يزوهشكَران به ينج گَزاره تقليـل يافت. در اين مقياس آزمودنى ها اظهار مى دارنـــــــهـــــاى مثــال،

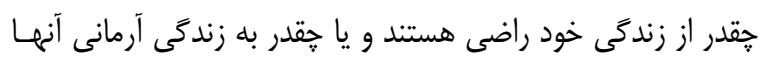
نزديك است. هر ززاره داراى هفت ززينه است كه از ا تا Vنمـره كذارى مى شود. داينر و همكاران پايايى مطلوبى براى اين مقيـاس كزارش كرده اند و آلفاى كرونباخ برابر هV٪ به دسـت آوردنــد و در

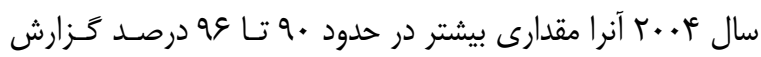
كردند[بr]]همجنين داينر و همكاران روايسى مطلـوبى را بـه شـكل افتراقى و همكَرا گزارش كرده اند كه نمايانكر همبستخى بالاى آن

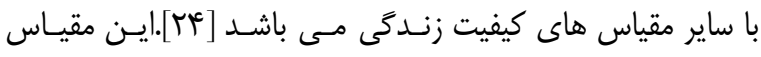
توسط خير وسامانى (ץ/ץו) براى استفاده در ايران هنجارسازى 
جدول شماره ( () ساختار و محتواى جلسات روايت درمانى تَروهى

\begin{tabular}{|c|c|}
\hline 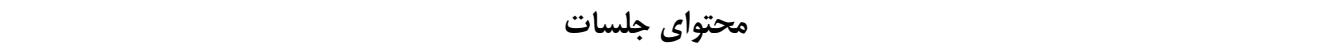 & \\
\hline آشنايى اعضا با يكديگر، برقرارى رابطه درمانى مبتنى بر يذيرش و تفاهم، بيان قواعد بنيادين گروه & جلسه \\
\hline 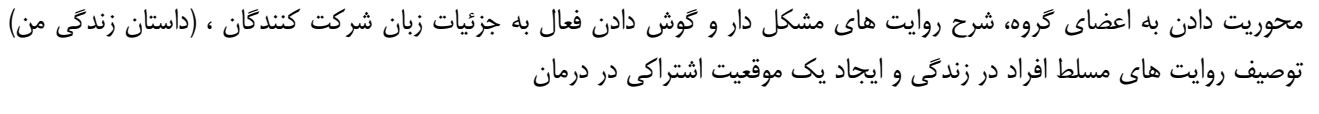 & دوه \\
\hline 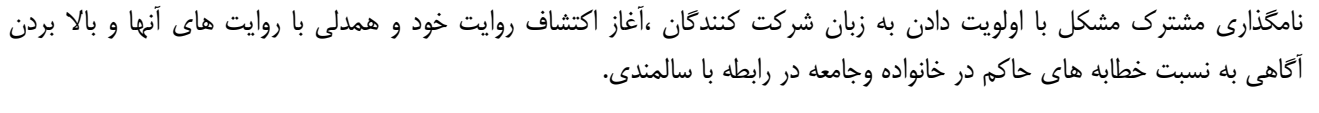 & سلسه \\
\hline 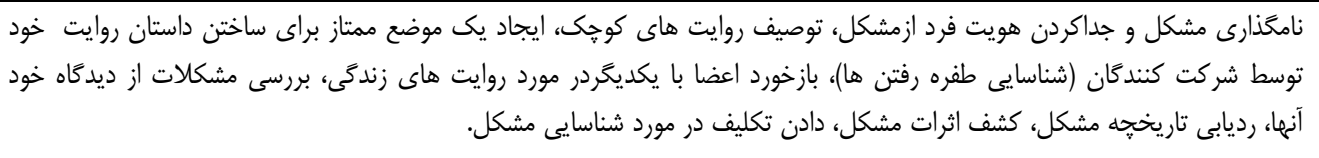 & جلسه \\
\hline 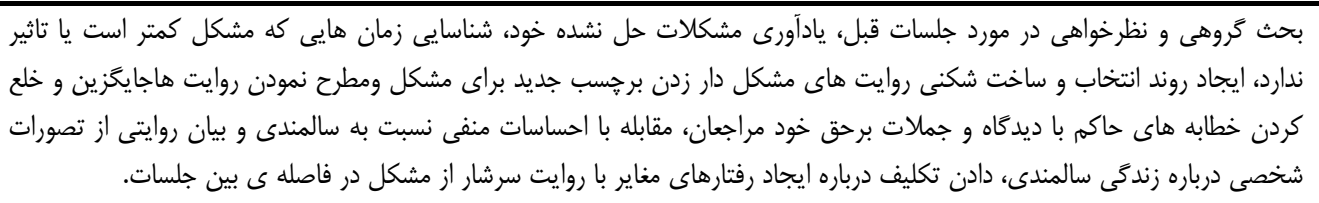 & جنجسم \\
\hline
\end{tabular}

شناسايى افراد مهم در زندكى فرد، درخواست از شركت كنندكان جهت نوشتن نامه هاى يست نشده، إيفاى نقش و توضيح تمرين جملات

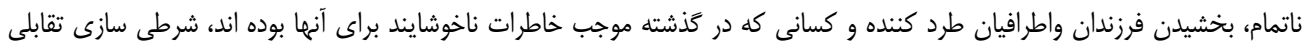

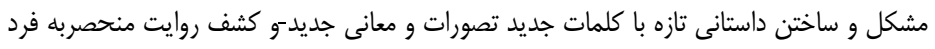

تجربه كردن جنبه هايى از خود توسط مراجعان كه قبلا آنرا تجربه نكرده بودند، تثبيت روايتها ومعانى جايخزين آزادى بخش، رديابى رئى 
حاكى از اين است كه باانجام مداخله آزمايشى، در ميان افراد گَروه

آزمايش در مراحل يِ آزمون و يِيخيرى افزايش ميانكَين در ميزان

$$
\text { رضايت از زندگى مشاهده مى شود . }
$$

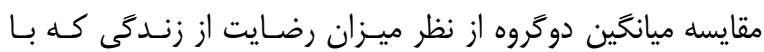
آزمون تى مستقل انجام شده، نشان مى دهد كـهـ در يــيش آزمـون

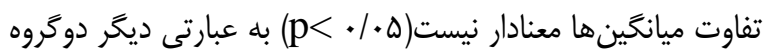
آزمون و كنترل بــه لحـاظ رضـايت از زنــدَى در ابتـداى آزمـايش تفاوتى وجود ندارد. اما نتايج تحليل كووارايانس ميانگين رضايت از زندگى دو گروه كنترل و آزمايش در يسس آزمـون و همجنـين در ييكيرى تفاوت معنادارى(ه+ (p< نشان داد.
يافته ها

اطلاعات جمعيت شناختى شركت كنندكان مطالعه حاضر در جدول ارائه شده است

\section{جدول ( () اطلاعات جمعيت شناختى(سن،تحصيلات،وضعيت اقتويت

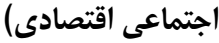
درصد (\%)
(n) تعداد القداد

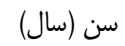
$\Delta \omega-9$.

r.

9) -90

ru

$<90$

تحصيلات

سו

is راهنمايى و يايين تر

r.

ديبلهم دانشخاهى دئم

r.

وضعيت اجتماعى-اقتصادى

بإيين

متوسط

19

بالا

\begin{abstract}
جدول (T) ميانگين و انحراف معياررا در ييش آزمون ،يس آزمون و ييخيرى براى گروههاى آزمون و كنترل نشان مىدهد. ايـن نتـايج
\end{abstract}

جدول r: تحليل توصيفى و استنباطى يافته هاى تحقيق

\begin{tabular}{|c|c|c|c|c|c|c|}
\hline معنادارى & تفاوتهان & خطاى معيار & انحراف & ميانكين & تروه & سطح \\
\hline \multirow[t]{2}{*}{ 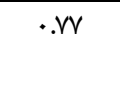 } & \multirow[t]{2}{*}{.98} & 1.5 & $f . V$ & 19.5 & آزمايش & ييش \\
\hline & & $1 . r$ & T.r. & $10 . V$ & كنترل & آزمون \\
\hline \multirow[b]{2}{*}{.1.} & \multirow[b]{2}{*}{$\mathrm{V} / \mathrm{I}$} & 1.19 & ig & THE & آزمايش & يֶ \\
\hline & & $1 . r$ & f.V & $10 . r$ & كنترل & آزمون \\
\hline \multirow[t]{2}{*}{$\because r$} & \multirow[t]{2}{*}{ T/FT } & I.V & 9.1 & 19.8 & آزمايش & \multirow[t]{2}{*}{ بيكيرى } \\
\hline & & 1.1 & $r / \mu$ & $10 . Y$ & كنترل & \\
\hline
\end{tabular}


بحث و نتيجه كَيرى

در واقع از آنجا كه روايت درمـانى بـر نقـش روايست و فرآينـدهاى روايتـى در سـازماندهى تحربيـات و دانـش و رفتــار تاكيــد دارنســـ مشكلات را ناشى از روايت هاى زنــدَى نامـهـ اى و تاريخخهـه اى مى داند كه به محتوايى مشكل مدار محدود شده انـــ كـهـ وايـتـ و إِتون ( •199) آنرا روايت هاى آغشته به مشـكل مسىدانتــد و در اين رابطه اين درمان مراجع را فعال كرده تا روايت هـاى شخصى خود را در فرآيند سازماندهى در سه مرحله شناسايى كند ا- مرحله ساختارزدايى، ז-مرحله ساخت مجدد و س-مرحلـه نهايى و تثبيـت [بץ] در طول مرحله ساختار زدايى هدف مركزى شناسـايى و فهـم مشكل در بافت و شرايط و فرض هـا ى خـاص آن و تـاثير آن بـر زندگى فرد در تلاش براى جداسـازى مشـكل از فـرد (برونسـازى) است. درمرحله ساخت دهى مجدد هدف اصلى درمان اين بـود كـهـ روايت هاى جديد كَترش يابد وتجربياتى كه خارج حيطـهـه روايـت هاى مسئله دار مانده اند به بــه عنـوان خـودروايتى فعـال فـرد بــهـ تدريج ظهور يابند كه اين عنصر جديد روايتى روايـت منحصـر بــــ فرد ناميده مىشود كه يك خود روايتى جايكزين را شكل مىدهـــ كه روابط انسانها را با خودشان، بـا تاريخشـان وديخــر افراد مهـهم زندكَيشان بازتعريف مى كند. درمرحلـهـ آخــــ يروتوكـل درمـانى كــــ مرحله نهايى و تثبيت است هدف تثبيت خـود روايتسى جـايخزين و وريشه داركردن آن در گَتتمان شبكه اجتماعى -فرهنكى وتمرين

$$
\text { وممارست درآن است[19]. }
$$

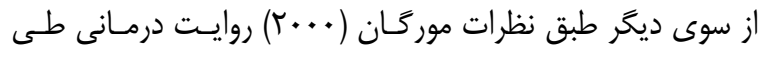
هفت مرحله صورت مى گيرد. برونسى سـازى: نامخـذارى مشـكل و جداكردن هويت فرد ازمشـكل، رديـابى تاريخهـهـ مشـكل، كشـف لـ

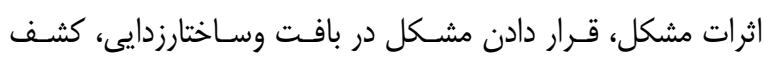

يزووهش حاضر با هـــف شـناخت اثربخشـ درمـان روايـت مــدار كروهى بــر ميـزان رضـايت از زنــدَى سـالمندان مسـتقر در خانسه سالمندان انجام شده نتايج يزوهش حاضــ نشـان داد كـه اجـراى درمان روايـت مـدار گروهـى موجـب افـزايش رضـايت از زنـدگى سالمندان مقيه خانه سالمندان مىشود و ايـن يافتـه در اثربخشى

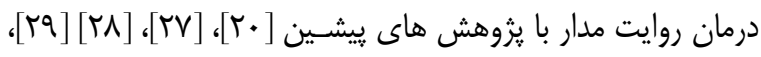

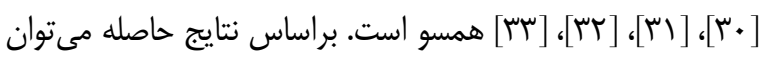
كفت اجراى اين روش درمانى سبب افزرايش احساسـات خوشـايند نسبت به زندكى و تغيير ديدگاه در جهت به دست آوردن احسـاس

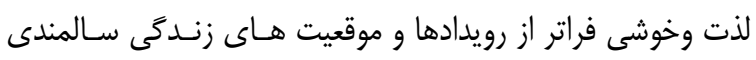
شده است. در تببين اين نتايج مى توان كفت كه سالمند در جريان روايت درمانى درمى يابد كه روايت مسلط زندكى اش نيازمند تغيير است و در زندگى او روايت هاى منحصر به فرد ديخرى نيـز وجـود دارد كه وى تا به حال بدانها توجه نكرده اسـت. همجنـين فـرد در مى يابد كه روايت هايى كه دارد از فرهنَ و ساختارهاى گسترده تر اجتماعى نيز تاثير مىيذيرد. و اين ساختارها هسـتند كـهـ روايـت هاى مسلط فرد را شكل مىدهند بر اين اساس مراجعان مى توانند خود را از اسارت در روابط هاى مشكل مــار كذشـته آزاد نماينــــ و لـ يك رويارويى بهتر با آينده اى با مشكلات كمتر داشته باشند[بr]. يكى ديگر از مهم ترين عنصر رويكرد روايت درمانى كـه توانستهـ در ارتقاى رضايت از زندگى موثر باشد توسعه و رشد روايـت هـاى جايخزين مى باشد كه در آن افراد مسئوليت يـذيرى بيشـترى رادر قبال ترجيح روايت هاى زندگَيشان دارند[هَ]. 
داشته،فرض هاى اساسى درمان روايت مدار مانند تاكيـد بـر نقــاط

قوت مراجعان است،در اين راستا درمانكر روايت مدار طى يك كفت

وكَى مشاركتى توجه مراجع را به توانمندى هايى معطوف مىدارد كه با ايجاد تغيير در روايت هاى زندكَيش مسىتوانـد از آنهـا بهـره كيرد[مبّ].و در اين رابطه بايد كَفت كه از آنجا كه فرد روايت مسلط خود را غرق در مشكلات ونقـصهـا مـىبينــد در تعريـف داسـتان خويش تنها به مشكلات فراوانى اشاره دارد[جَ] لذا اين توجه بيش از حد به مشكلات و روايت هاى مشكل زا اجازه تجربه لحظـات و معناهاى منحصر به فرد را به سالمند نمى دهد و در اين درمـان بـاــا ايجاد روايت هاى جديد در اين رابطه اقدام مىشود. فرض اساسى ديخر در روايت درمانى اين عقيده است كـه درمـانكر و مراجـع بـهـ

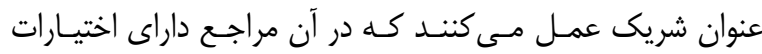
فراوان ونظرات قابل يذيرش ومورد احترام است [Nب] نه يك رابطه درمانى خشك و غير قابل انعطاف. تمامى اين مكانيسـمهــا نهايتـا سبب تاثير گذارى اين درمان بر گروه آزمايش شده است.

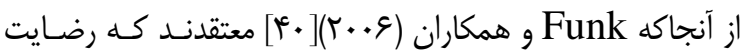
درونى و رضايت از زندگى از رشد فردى و اجتماعى ومنابع سازشى نشات مى گيرد در اينجا نيز روايت درمانى توانسته است بـهـ عنـوان يك منبع سازشى عمل كند و رضـايت از زنــدى سـالمندان مقـيم خانه سالمندان را افزايش دهد و ايـن افززايش نيـز در يـى كيـرى همجِنان ادامه يافته است. از محدوديت هايى كـه يزوهشـحَران در اين يزوهش با آنها روبرو بودند مىتوان به يِيجيدگى ايـن رويكـرد بـراى مراجعـان در فراينـــــلسـات آمـوزش گروهـى و همرنـين مقاومت در بيان روايتها در گروه مىتوان نام برد، اقامت طـولانى مدت در سراى سالمندان سبب نـوعى بـى حوصـلكَى و بــــ بينسى نسبت به جلسات مداخله اى شده كه جلسات را تحت تاثير قرار داد
خروجى منحصربه فرد وشناسايى زمان هايى كه مشكل كمتر است يا تاثيرى بر فرد نداشته است، رديـابى تاريخهـهـه و معنــاى روايـت منحصر به فرد و نامخذارى روايت جـايكزين و نهايتـا تقويـت ايـن روايت جايكزين[عَ]در اين يزوهش نيز اين V مرحله قابل رديابى است كه در مجموع توانسـته رضـايت از زنــــى سـالمندان گَروه آزمايش را افزايش دهد. و اين مداخله توانسته روايت هاى مراجعان كروه آزمايش را به سمت و سوى منحصر به فرد تر و آزادى بخش تر از روايت هاى مسلط ناساز كارانه فرد رهنمـون شـود كـه دسـت يابى به اين روايت ها با تكيه بـر مســوليت ِـــيرى خـود مراجـان صورت گرفت. از سوى ديخـــ فراينـدهاى اساسـى درمـانى كـه در روايت درمانى مطرح است كه شـامل افـزايش آَكاهـى نسـبت بــهـ

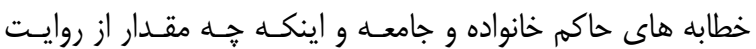
زندگى ما توسط خانواده و جامعه شكل گرفتنه[عس]و اينكه خه مقدار از تفكرات درباره سالمندى توسط آنها شكل كرفته است؛ و توجه به موضـع ممتـاز مراجــان در سـاختن روايتـى منحصـر بـهـ فـرد از زندگى[أI][توانسته در اين افزايش رضايت از زندكى مراجعان نقش ايفا كند، مكانيسم ديخرى كه در اين درمان تاثير كذار است انتخاب است كه كه شامل نـوعى آمـادحى بـراى روايتـى نـو از كذشـته و زندگى حال سالمندى و تصميم گَيرى براى معنى دادن به جملات، تجربيات و بخش هاى از زندگى [TV] است كه مدت هــا فرامـوش شده اند و در اين زمينه تكنيك هاى دفتر خاطرات، نامه هاى ֶٍت نشده بيشتر مورد استفاده قرار كَرفت. فرآيند درمـانى سـوم وشـايد

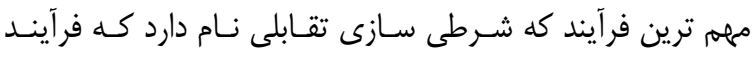
تجديد بنا و ترسيه روايت هاى جديد و دوباره تاليف شدن داستان زندگى از طريق گفت و گوهاى درمانى است. از طرف ديخَر ويزَى ديخـــر ايـن درمـان كـهـ مسى تـوان كَفـت در اثربخشـى آن نقـش 


$$
\begin{aligned}
& \text { و كاها به عدم همكارى فعالانـهـ مسىانجاميـد. درنهايـت بـه سـاير } \\
& \text { يزوهشگَران توصيه مىشود كه با بهره گيرى از نمونه هاى بزرَتـر } \\
& \text { و نيز تمركز بر زنان و مردان سالمند به صورت توام و در فرهنگَها } \\
& \text { و قوميت هاى ديخر تحقيقات بيشترى در اين زمينه انجام شـود تـاـ } \\
& \text { تعميم يذيرى يافتها افزايش يابد؛ و در نهايت بر اساس يافته هاى } \\
& \text { اين يزوهش بيشنهاد مىشود روانشناسـان ، مشــاوران ، مـددكاران } \\
& \text { اجتماعى و ساير حرفه هاى يارى رسان توجه بيشترى به مداخلات } \\
& \text { بالينى در رابطه با سالمندان معطوف دارند كه روايت درمانى يكى از }
\end{aligned}
$$

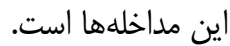

\section{- References}

1. United Nations, Department of economic and social affairs, population division. World Population Ageing 2013. ST/ESA/SER.A/34.

2. WHO. ["Interesting facts about ageing," www.who.int [Online]. Available: http://www.who.int/ageing/about/facts/en/ [Accessed: Apr. 3, 2014].

3. Yang-Yen Ou Po-Yi Shih Yu-Hao Chin Ta-Wen Kuan Jhing-Fa Wang and Shao-Hsien Shih .[ Framework of ubiquitous healthcare system basedon cloud computing for elderly living.] Journal of Apsipa , 2013 :16-27.

4. The overall Results of the General Census of Population and Housing 2006-2007. Presidency of the I.R.I, VicePresidency for Strategic Planning and Supervision, Statistical Centre of Iran, 2007.

5. Yavari, Hamid Reza, et al. [Association between polypharmacy and socio-demographic factors among elderly residents of kahrizak charity foundation,] Tehran, 2010-2011." Iranian Journal of Ageing, 2014: 7-14. (Persian)

6. Megalingam R.K., G. Pocklassery, G. M, and Jayakrishnan, v. ["Elder health care: Blood Pressure measurement]. India Conference (INDICON), 2012 Annual IEEE, 747—752. 
7. Diener, E. D., Emmons, R. A., Larsen, R. J., \&Griffin, S. [The satisfaction with life scale]. Journal of Personality Assessment, 1985: 49, 71-75.

8. Hejazi, E ,Salehnajafi, M \& Amani ,J [The mediating role of intrinsic motivation on the relationship between basic psychological needs and life satisfaction]. Contemporary Psychology, 2015: 9(2), 77-88.

9. Raziyye;J, Golzaei, M, [The effectiveness of hope therapy on increasing happiness and life satisfaction among elderly women residing in nursing home of borujen] .Quarterly Journal of women and society, 2014: 5 ( 2) 18-22 (Persian).

10. Meléndez, J. C., Tomás, J. M. et al. [Psychological and physical dimensions explaining life satisfaction among the elderly: A structural model examination.] Archives of Gerontology and Geriatrics 2009: 48(3): 291-295.

11. Kamaly, R. [Comparison level of satisfaction of elders living in nursing home with elders living with family] Bachelor Thesis, Allameh Tabatabai University 2014. (Persian).

12. Prochaska, J.O. \& Norcross, J.C. (2007). Psychotherapy systems, (Tr.) by Yahya Seyyed Mohammadi, (2012), Tehran, Ravan Publications.

13. Milojević, I. [Creating alternative selves: the use of futures discourse in narrative therapy.] Journal of Futures Studies, March 2014, 18(3): 27-40.

14. White, M. \& Epston, D. (1990). Narrative means to therapeutic ends. New York: WW Norton.

15. Worthham, s. [Narrative in action.a strategy for research and analysis], New York:Teachers college press.2001.P.87.

16. Lopesa, R, T. Gonçalvesa, M, M. Machadoa, P ,P, Sinaib, D. B, \& Salgado J. [Narrative therapy vs. cognitive-behavioral therapy for moderate depression]. Empirical evidence from a controlled clinical trial. Psychotherapy Research, 2014:4(8):45-54.

17. Bassak Nejad, S., Mehrabizadeh Honarmand, M, Hasani, M, Nargesi. F. [The Effect of narrative group therapy on body dysmorphic concern in female university students]. Health Psychology 2012:2. (Persian)

18. NTCT (Narrative Therapy Centre of Toronto). [About Narrative Therapy]. Retrieved on July 29, 2013, from: http://www.narrativetherapycentre.com/narrative.

19. White, M. [Narrative practice; reflections on narrative practice adelaide], South Australia: Dulwich Centre Publications, 2000.P.198-214. 
20. Mackean, S. [Comparison of the effects of narrative therapy and diet therapy on the body mass index in overweight and obese women.]. Iranian Journal of Nutrition Sciences \& Food Technology .2011: 5(4): 0-0. (Persian).

21. Sanagoo A, Bazyar, A, Chehrehgosha M, Gharanjic S, Noroozi M, Pakravan far S, et al. [People Attitude toward Elderly in Golestan Province] ,2012; 8 (2):24-29 (Persian).

22. Scogin,F\& McElreath,L. [Efficacy of psychosocial treatment for geriatric depression:A quantitative review]. Journal of Consulting and Clinical Psychology,1994: 62,69-74

23. Eid, M., \& Diener, E. [Global judgments of subjective well-being: Situational variability and long-term stability]. Social Indicators Research, 2004: 65, 245-277.

24. Inglehart, R, Tay, L. [Theory and validity of Life satisfaction scales]. Social Indicators Research, Evaluating Life Satisfaction Measures, 2012.P.88.

25. Nasiri, H. Jokar, B. [Meaning in life, hope, life satisfaction and mental health in women]. Journal of Research Women. (2008):1(2).157-176. (Persian).

26. Morgan, Alice. [What is narrative therapy? an easy-to-read introduction].Adelaide, SA: Dulwich Centre, 2000.P.154.

27. Nuri-Tirtashi, E. M. A., Kazemi, N. M. A. [The effectiveness of narrative therapy on amount of forgiveness in women]. Journal of Clinical Psychology, 2012:4(2). [Persian].

28. Betchley, D., \& Falconer, W. [Giving Colin a voice: The challenge of narrative therapy with a client who has anintellectual disability and communication difficulties]. Australian Social Work, 2002: 55, 3-12.

29. Cashin, A. [Narrative Therapy: A psychotherapeutic approach in the treatment of adolescents with Asperger's disorder]. Journal of Child and Adolescent Psychiatric Nursing, 2008: 2.

30. Palgi, Y., \& Ben-Ezra, M. ["Back to the future": Narrative treatment for post-traumatic, acute stress disorder in the case of paramedic] Mr. G. Pragmatic Case Studies in Psychotherapy, 2010: 61-26.

31. Young, E. [Narrative therapy and elders with memory loss]. Clinical Social Work Journal, 2008:38, 193-202.

32. Matos, M., Santos, A., Gonçalves, M. M., \& Martins, C. [Innovative moments and change in narrative therapy. Psychotherapy research] Journal of the Society for Psychotherapy Research, 2009: 19, 68-80. 
33. Bagheri nia, H. Mehri, Z, Davoodi, Z \& Sadat Dehghani, F. [Influence of Narrative therapy on adjustment rate of mentally retarded boys and girls living Esfarayen City]. International Research Journal of Applied and Basic Sciences. 2014: 8 (12): 2263-2268

34. Freedman, J \& Combs, G. [Narrative therapy with couples and a whole lot more! a collection of papers, essays and exercises] Adelaide,S A: Dulwich Centre,2002.P.45.

35. Bohlmeijer ET, Kramer J, Smit F, Onrust S, van Marwijk H. [The effects of integrative reminiscence ondepressive symptomatology and mastery of older adults.Community Mental Health Journal 2009: 45, 476-484.

36. Mcnamee, s,\& gergen,k,j. [Therapy as social construction] London.:sage,1992.P.98.

37. Omer, H. [Narrative empathy] .Psychotherapy. 1997: 34, 19-27.

38. Polkinghorne,D. E.[Narrative therapy and postmodernism.in angus the hand book of narrative and psychotherapy]. Sage Publications India pvt.Ltd:2004.P.165.

39. Rabiee S; Fatehi Zadeh, M, Bahrami, F. Narrative Therapy [Quarterly Journal of Psychoterapical Novelties,] 2005: (13) 47-48. ( Persian).

40. Funk III, B. A., Huebner, E. S., \& Valois, R. F. [Reliability and validity of a brief life satisfaction scale with a high schoolsample]. Journal of Happiness Studies, 2006: 7, 41-54. 